\title{
Arbuscular mycorrhizal colonisation increases copper binding capacity of root cell walls of Oryza sativa L. and reduces copper uptake
}

\author{
Xu-Hong Zhang ${ }^{\mathrm{a}, \mathrm{b}}$, Ai-Jun Lin ${ }^{\mathrm{c}}$, Yan-Ling Gao ${ }^{\mathrm{b}}$, Rob J. Reid ${ }^{\mathrm{d}}$, Ming-Hung Wong ${ }^{\mathrm{e}}$, Yong-Guan Zhu ${ }^{\mathrm{a}, *}$ \\ ${ }^{a}$ Research Center for Eco-Environmental Sciences, Chinese Academy of Sciences, Beijing 100085, People's Republic of China \\ ${ }^{\mathrm{b}}$ Beijing City University, Beijing 100083, People's Republic of China \\ ${ }^{\mathrm{c}}$ Department of Environmental Science and Engineering, Beijing University of Chemical Technology, Beijing 100029, People's Republic of China \\ d School of Earth and Environmental Sciences, The University of Adelaide, Adelaide, South Australia 5005, Australia \\ e Department of Biology, Hong Kong Baptist University, Kowloon Tong, Kowloon, Hong Kong, SAR, People's Republic of China
}

\section{A R T I C L E I N F O}

\section{Article history:}

Received 2 March 2008

Received in revised form 9 August 2008

Accepted 11 August 2008

Available online 5 September 2008

\section{Keywords:}

Arbuscular mycorrhizae

Copper uptake

Cell wall

Hemicellulose

Pectin

Rice

\begin{abstract}
A B S T R A C T
There is evidence that colonisation by mycorrhizal fungi can protect host plants from toxic concentrations of heavy metals. The mechanism by which protection is provided by the fungus for any particular metal is poorly understood. Rice (Oryza sativa L.) plants were inoculated with Glomus mosseae and grown for 4 weeks to ensure strong colonisation. The plants were then exposed to low to toxic concentrations of copper $(\mathrm{Cu})$ and the uptake and distribution were examined. The effect of mycorrhizal colonisation on the cell wall composition and $\mathrm{Cu}$ binding capacity of roots was also investigated. Mycorrhizal plants showed moderate reductions in $\mathrm{Cu}$ concentrations in roots but large reductions in shoots. In roots, mycorrhizal plants accumulated more $\mathrm{Cu}$ in cell walls but much less in the symplasm compared to nonmycorrhizal plants. The differences in cell wall binding of $\mathrm{Cu}$ could be partly explained by changes in the composition of the cell wall. The mechanistic basis for the reduced $\mathrm{Cu}$ accumulation and the potential beneficial consequences of mycorrhizal associations on plant growth in $\mathrm{Cu}$ toxic soil are discussed.
\end{abstract}

(c) 2008 Elsevier Ltd. All rights reserved.

\section{Introduction}

Plant tolerance to heavy metals can be achieved through a range of physiological and morphological changes (Sanitá di Toppi and Gabbrielli, 1999; Hall, 2002). Metal retention by roots is often cited as a beneficial strategy (Wagner, 1993), although in few cases has the site of increased metal storage in roots been identified. Similarly, some mycorrhizal fungi have been shown to reduce accumulation of certain heavy metals in shoots and it is presumed that this is due to increased retention within the root/mycorrhizal structures (Brunner and Frey, 2000; Chen et al., 2004; Zhang et al., 2005). There are a number of possible explanations for the observed reductions in heavy metal concentrations in shoots of mycorrhizal plants. These include (1) a greater selectivity of metal transporters in the cell membranes of mycorrhizae, (2) compartmentation of metals in fungal vacuoles, thereby reducing transfer of the metals to the plant, and (3) increased capacity of mycorrhizal roots to immobilise metals within their cell walls. The binding of heavy metal ions to plant root most probably involves charged groups on cell wall polysaccharides binding metal efficiently (Cohen-Shoel et al., 2002). Of these the acidic side groups of

\footnotetext{
* Corresponding author. Tel.: +8610 62936940; fax: +861062923563. E-mail address: ygzhu@rcees.ac.cn (Y.-G. Zhu).
}

galacturonic acid in pectin are likely to be most important. (Eticha et al., 2005). Pectins have been implicated as the main cell wall binding site for $\mathrm{Al}^{3+}$ (Eticha et al., 2005).

Evidence for intracellular sequestration of metals in ectomycorrhizal fungi is largely indirect and metal-specific (Blaudez et al., 2000; Frey et al., 2000). However, there appear to be no data on relative metal selectivity between plants and endomycorrhizal fungi; the obligate nature of the endomycorrhizal association makes it difficult to separate binding to plant root from binding to the fungus. Adsorption on or precipitation of heavy metals in plant cell walls has been reasonably well described (Lignell et al., 1982; Pellegrini et al., 1993; Amado Filho et al., 1999; Andrade et al., 2002), but there is limited information on metal binding by mycorrhizal cell walls. Joner and Leyval (1997) reported that the arbuscular mycorrhizal fungus Glomus mosseae had a high capacity for $\mathrm{Cd}$ uptake but they did not distinguish between immobilization on cell walls or in vacuoles. Tam (1995) demonstrated that in the ectomycorrhizal fungus Pisolithus tinctorius, $\mathrm{Cu}$ and $\mathrm{Zn}$ were retained in extrahyphal slime, while Bradley et al. $(1981,1982)$ showed that in the dwarf shrub Calluna vulgaris (L.), $\mathrm{Cu}$ accumulated in the associated ericoid mycorrhizal fungus Pezizella ericae. Despite the apparent versatility of different types of mycorrhizae to accumulate heavy metals, how this is achieved largely remains a mystery.

Rice is an important crop in Asia, especially in China. However, contamination with a mixture of heavy metals of paddy soils is not 
uncommon (Chen et al., 2005; Lin et al., 2007). Based on evidence with other heavy metals (Brunner and Frey, 2000) mycorrhizal associations with rice could potentially reduce the uptake of $\mathrm{Cu}$. In this study we have focused on the role of cell walls in binding of $\mathrm{Cu}$ in the association between rice and the arbuscular mycorrhizal fungus G. mosseae. The principal aim was to try to establish whether reduced uptake of copper could be explained by compositional changes in cell walls of roots as a result of mycorrhizal colonisation.

\section{Materials and methods}

\subsection{Cu toxicity trial}

Seeds of rice (Oryza sativa L.) cultivars, Jiahua 1, were surfacesterilized with $10 \%(\mathrm{v} / \mathrm{v}) \mathrm{H}_{2} \mathrm{O}_{2}$ for $10 \mathrm{~min}$ and immersed in deionized water for $24 \mathrm{~h}$. They were then germinated on moist filter paper until the radicles appeared. For each treatment, 20 uniform seedlings were placed in $20 \mathrm{ml}$ of treatment solution $\left(\mathrm{KNO}_{3}\right.$ $0.2 \mathrm{mM}$, $\left.\mathrm{Ca}\left(\mathrm{NO}_{3}\right)_{2} 0.2 \mathrm{mM}, \mathrm{MgSO}_{4} 0.1 \mathrm{mM}\right)$ with varying concentrations of $\mathrm{Cu}$ supplied as $\mathrm{Cu}\left(\mathrm{NO}_{3}\right)_{2}$. The solutions were changed every $12 \mathrm{~h}$ for 7 days then the root lengths were measured.

\subsection{Production of mycorrhizal and non-mycorrhizal plants}

Since the presence of different concentrations of $\mathrm{Cu}$ in the medium during the inoculation and colonisation of plants by the mycorrhiza could potentially lead to variations in the degree of colonisation that would complicate interpretation of the results, plants were precultured without $\mathrm{Cu}$ for 4 weeks until strong and uniform colonisation was established. Plants were then exposed to $\mathrm{Cu}$ over the following 2 weeks to examine the uptake and distribution of $\mathrm{Cu}$.

Rice seeds were surface-sterilized with $10 \%(\mathrm{v} / \mathrm{v}) \mathrm{H}_{2} \mathrm{O}_{2}$ for $10 \mathrm{~min}$ and immersed in deionized water for $24 \mathrm{~h}$. They were then germinated on moist filter paper until the radicles appeared. The seedlings were selected for uniformity before planting. $O$. sativa $\mathrm{L}$. was inoculated with G. mosseae isolate (Gm) (BGC.XJ01, isolated from a non-contaminated soil, provided by YS Wang, Beijing Academy of Agriculture and Forestry) or left uninoculated (NM). The inoculum contained dried roots of sorghum, hyphae, spores and soil. Plants were grown in round plastic pots containing $200 \mathrm{~g}$ perlite plus $40 \mathrm{~g}$ inoculum for the mycorrhizal treatment, or $200 \mathrm{~g}$ perlite plus $40 \mathrm{~g}$ sterilized inoculum for the NM treatment. The inoculum was mixed with the perlite. Three germinated seedlings were sown per pot. Containers were watered and fertilized as needed with a $1 / 5$ strength nutrient solution (Feigin et al., 1987). Pots were regularly weighed to maintain appropriate water content. After 4 weeks of preculture, some plants were removed gently from perlite, and were washed carefully to remove adhering particles on the root surface. Plants were then transferred to hydroponic treatment solutions containing varying concentrations of $\mathrm{Cu}$ for 2 weeks; other plants were grown for a further 4 weeks in perlite without $\mathrm{Cu}$ to provide material from which to extract cell walls for the $\mathrm{Cu}$ binding studies. For the hydroponic experiment, inoculated roots showing good colonisation, along with NM roots, were transferred into $1 / 4$ strength modified Hoagland's nutrient solution with or without $\mathrm{Cu}$. Fe-EDTA was omitted from uptake solutions to avoid complexation of $\mathrm{Cu}$. The $\mathrm{pH}$ of uptake solutions was maintained at 5.5. During the growth period, the containers were aerated with air pumps and arranged in an environmentcontrolled growth chamber with a 14 -h photoperiod at a photon flux $280 \mu \mathrm{mol} \mathrm{m}^{-2} \mathrm{~s}^{-1}$ in the range $400-700 \mathrm{~nm}$.

\subsection{Root colonisation by G. mosseae}

To determine the degree of colonisation after 4-week and 8 -week preculture, a portion of the roots (about $1 \mathrm{~g}$ fresh weight) was washed free of perlite with tap water, and then fully rinsed in deionized water. The clean roots were cut into segments around $1 \mathrm{~cm}$ long, cleared by soaking in $10 \% \mathrm{KOH}$ and stained according to Phillips and Hayman (1970) but without using phenol. Percentage colonisation was determined by the grid intersect method (Giovannetti and Mosse, 1980).

\subsection{Distribution of $\mathrm{Cu}$ between root apoplast and symplast}

In order to distinguish between $\mathrm{Cu}$ bound to cell walls and $\mathrm{Cu}$ taken up into cells, roots were desorbed using a modified desorption procedure as described in Reid and Liu (2004). Briefly, after being treated with different concentrations of $\mathrm{Cu}$ in hydroponic solution, roots were excised. The entire root system from each treatment was then desorbed in $5 \mathrm{mM} \mathrm{CaCl}_{2}$, which was changed every $5 \mathrm{~min}$. After $20 \mathrm{~min}$ the roots were rapidly frozen in liquid nitrogen to disrupt cell membranes and desorption was continued for $40 \mathrm{~min}$. The $\mathrm{Cu}$ released in the $20 \mathrm{~min}$ desorption plus the $\mathrm{Cu}$ remaining in the root after the freeze-thaw plus rinse was considered to be apoplastic. The $\mathrm{Cu}$ released following the freezethaw was considered symplastic. The $\mathrm{Cu}$ concentration in the desorbed solution and in the solution after freeze-thaw was analyzed directly by inductively coupled plasma-atomic emission spectroscopy (ICP-AES).

\subsection{Measurement of tissue $\mathrm{Cu}$ content}

Plants were harvested at the end of the treatments and the roots rinsed with Milli-Q water and blotted gently. The roots and shoots were oven-dried at $70^{\circ} \mathrm{C}$ for $72 \mathrm{~h}$ and the dry weights determined. The dried samples were ground with a stainless steel mill and digested in concentrated nitric acid $\left(\mathrm{HNO}_{3}\right)$ at $160{ }^{\circ} \mathrm{C} . \mathrm{Cu}$ in the extracts was measured by ICP-AES.

\subsection{Preparation of cell walls}

Root cell walls of 8 weeks mycorrhizal and non-mycorrhizal plants were extracted according to Zhong and Lauchli (1993). Roots were frozen in liquid $\mathrm{N}_{2}$ and homogenized to a powder with a mortar and pestle. The root powder was washed into a $50-\mathrm{ml}$ centrifuge tube with three aliquots of $15 \mathrm{ml}$ ice-cold $75 \%$ ethanol, mixed well and left undisturbed for $20 \mathrm{~min}$ in an ice bath. The homogenates were then centrifuged for $10 \mathrm{~min}$ at $1000 \mathrm{~g}$ and the pellets were washed in three steps, each repeated three times, as follows: 1) ice-cold acetone $(1: 7, w / v), 2)$ ice-cold methanolchloroform mixture $(1: 1, \mathrm{v} / \mathrm{v})$ and 3$)$ ice-cold methanol. The supernatant of each wash was discarded and the final pellet was freeze-dried overnight. The dried pellets were further ground to powder with a mortar and pestle and considered as crude cell walls. The powder was stored at $4{ }^{\circ} \mathrm{C}$ until required.

\subsection{Fractionation of cell walls}

Individual cell wall components were extracted according to Zhong and Lauchli (1993). The crude cell walls of mycorrhizal and non-mycorrhizal roots $(0.1 \mathrm{~g})$ were incubated in $4 \mathrm{ml} 0.5 \%$ ammonium oxalate buffer (containing $0.1 \% \mathrm{NaHB}_{4}$ ), and washed twice in boiling water for $2 \mathrm{~h}$. After centrifugation the supernatants were collected, considered as pectin, and the volume was recorded. The precipitate was washed with deionized water twice and freezedried. The dried precipitate was washed with $4 \mathrm{ml} 4 \% \mathrm{NaOH}$ (containing $0.1 \% \mathrm{NaHB}_{4}$ ) three times for $24 \mathrm{~h}$ at room temperature. After centrifugation the supernatants were collected and the volume was recorded. After being neutralized with cold acetic acid, the supernatant was freeze-dried and designated hemicellulose 1 (HC1). In the same way the precipitate was washed and freeze- 
dried, then washed in $4 \mathrm{ml} 24 \% \mathrm{NaOH}$ (containing $0.1 \% \mathrm{NaHB}_{4}$ ) three times for $24 \mathrm{~h}$ at room temperature and the supernatant was collected. This supernatant was designated hemicellulose 2 (HC2). The extracted solution was kept at $4{ }^{\circ} \mathrm{C}$ for further use. The concentration of uronic acids in different parts of the cell walls was determined according to Taylor and Buchanan-Smith (1992).

\section{8. $\mathrm{Cu}$ binding assays}

Binding of $\mathrm{Cu}$ was measured by monitoring the depletion from solution following addition of cell walls or cell wall fractions. $\mathrm{Cu}$ concentrations in solution were determined using a $\mathrm{Cu}^{2+}$ ionselective electrode (Orion 9629B, Thermo Orion, USA) (Cu-ISE). Calibration curves were prepared using $\mathrm{Cu}\left(\mathrm{NO}_{3}\right)_{2}$ in deionized water. The ionic strength of the solutions was matched using $\mathrm{KNO}_{3}$. The $\mathrm{pH}$ was adjusted to 5.5 with $\mathrm{HNO}_{3}$ or $\mathrm{KOH}$. The activity of $\mathrm{Cu}^{2+}$ in the standards was calculated using Geochem-PC (ver. 2) (Parker et al., 1993) which estimated that about $90 \%$ of the Cu was free $\mathrm{Cu}^{2+}$ at $\mathrm{pH}$ 5.5. The calibration curve typically had a slope around $-28.2 \mathrm{mV} \mathrm{pCu}^{-1}$ and was linear over the range $\mathrm{pCu} 2-7$ $\left(R^{2}=0.9947\right)$. The various root fractions $(0.1 \mathrm{~g} \mathrm{DW})$ were incubated in $50 \mathrm{ml} \mathrm{Cu}$ solutions and uptake monitored over $1 \mathrm{~h}$.

\subsection{Statistics}

Results are presented as mean \pm standard error of the mean. Data were tested by two-way analysis of variance by SAS software 6.0 and means were compared by LSD at the $5 \%$ level.

\section{Results}

\subsection{Cu toxicity}

A preliminary experiment was conducted to assess the toxicity of $\mathrm{Cu}$ to the growth of rice in hydroponic culture. Root elongation was measured from germination to 7 days at different $\mathrm{Cu}$ concentrations. $\mathrm{Cu}$ concentrations up to $1 \mu \mathrm{M}$ had weakly positive or no effects on root growth compared to no $\mathrm{Cu}$ addition, while $5 \mu \mathrm{M} \mathrm{Cu}$ reduced root elongation by $90 \%, 10 \mu \mathrm{M}$ and higher $\mathrm{Cu}$ concentrations reduced growth by $>95 \%$.

\subsection{Plant growth under different $\mathrm{Cu}$ addition levels}

Mycorrhizal colonisation was approximately 50\% at the beginning of the $\mathrm{Cu}$ treatments ( 4 weeks) but was reduced to approximately $40 \%$ at the end of the experiment ( 8 weeks) (Fig. 1).

\subsection{Cu accumulation in mycorrhizal and non-mycorrhizal plants}

During the 2-week incubation period in Cu-containing growth solutions, approximately $90 \%$ of plant $\mathrm{Cu}$ was retained in the roots (Fig. 2). The differences in root Cu concentration between non-toxic $(1 \mu \mathrm{M})$ and toxic $(5 \mu \mathrm{M})$ were relatively small. However, with increasing toxic concentrations, there was a noticeable trend in which the $\mathrm{Gm}$ plants accumulated significantly less $\mathrm{Cu}$ than the NM plants; this difference was more striking in the shoots at 5 and $100 \mu \mathrm{M} \mathrm{Cu}$ where the shoot $\mathrm{Cu}$ concentration in the $\mathrm{Gm}$ plants was less than $10 \%$ and $48 \%$ of those in the NM plants, respectively (Fig. 2a).

\subsection{Cu distribution between symplast and apoplast in roots}

The overall concentration of $\mathrm{Cu}$ in roots is comprised of both intracellular and extracellular fractions. The use of combined desorption and freeze-thaw techniques to separate the two fractions revealed that $\mathrm{Gm}$ plants accumulated more $\mathrm{Cu}$ in their cell
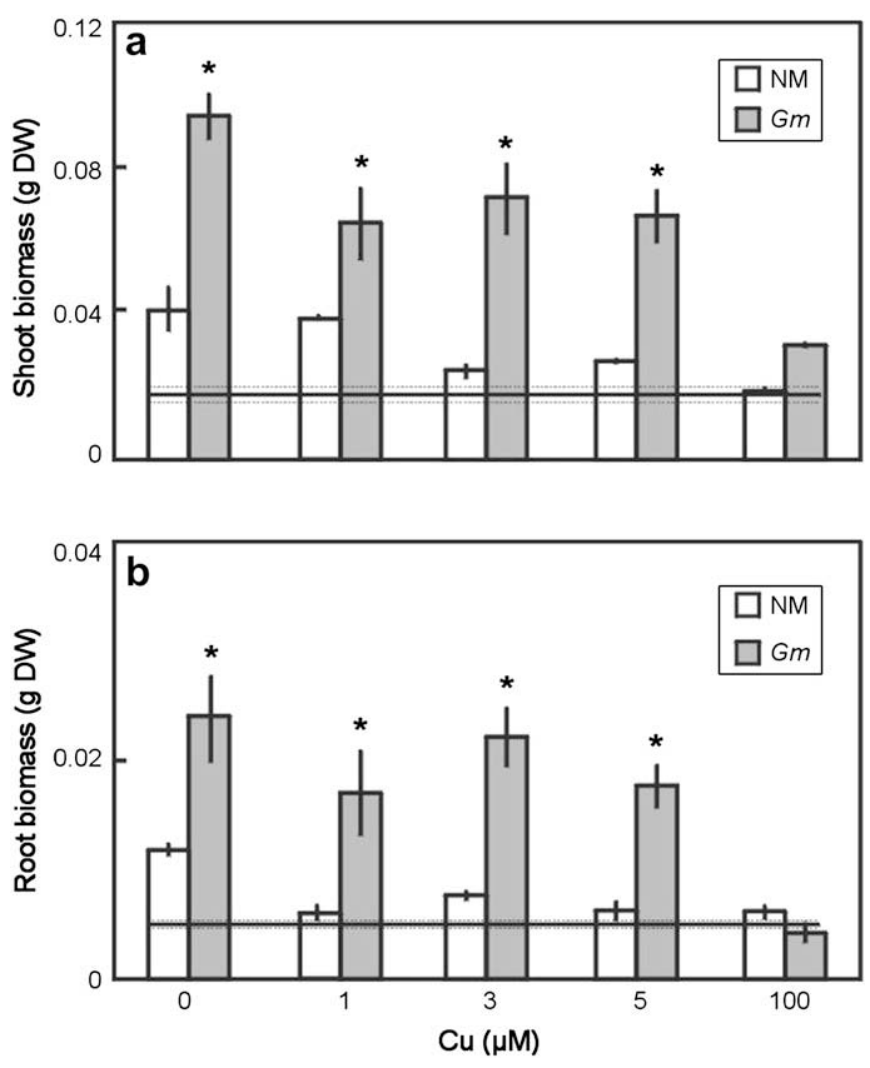

Fig. 1. Dry matter yield of $O$. Sativa $L$. under different $\mathrm{Cu}$ addition levels. Plants were pre-cultured without $\mathrm{Cu}$ for 4 weeks then $\mathrm{Cu}$ treatments were applied for a further 2 weeks before harvest. The horizontal line indicates the mean root and shoot biomass at 4 weeks. Data are means \pm standard error of the mean. $n=4$ for dry matter yield of $O$. Sativa L. Asterisks indicate significant differences $(P<0.05)$.

walls than NM plants, and conversely, that NM plants absorbed more $\mathrm{Cu}$ into the root cells compared to the $\mathrm{Gm}$ plants (Fig. 3).

\subsection{Binding on cell walls}

Purified cell walls were found to have a high capacity for binding $\mathrm{Cu}$, with saturation only being achieved at around $1.5 \mathrm{mM} \mathrm{Cu}$ at $\mathrm{pH}$ 5.5 (Fig. 4). Nevertheless, for the same weight of cell wall material, Gm plants were able to bind significantly more $\mathrm{Cu}$ than NM plants across the entire concentration range tested in these experiments (Fig. 4). Fig. 5a shows a typical time course of binding of $\mathrm{Cu}$ in cell walls. Adsorption of $\mathrm{Cu}$ was rapid with saturation of binding sites being achieved within $10 \mathrm{~min}$. There were no large differences in the rate of $\mathrm{Cu}$ binding in cell walls from NM and $\mathrm{Gm}$ plants, but the steady-state concentration of $\mathrm{Cu}$ was significantly higher in $\mathrm{Gm}$ plants. Treatment of the isolated cell walls to remove pectin and some of the hemicellulose resulted in a moderate reduction in the binding capacity of roots from the NM plants, but a much greater reduction in binding in the $\mathrm{Gm}$ plants (Fig. 5b).

\subsection{Cell wall content and composition of mycorrhizal and non-mycorrhizal plants}

Cell walls were extracted from NM and Gm plants that had been grown for 8 weeks without $\mathrm{Cu}$. At this stage the average colonisation of inoculated roots was more than $40 \%$, with no colonisation in the control plants. There was a small but significant increase in the proportion of cell walls in Gm plants compared to NM plants (i.e. for the same fresh weight, for $\mathrm{Gm}$ plants the combined cell wall production from plant plus fungus was higher) (Table 1). 


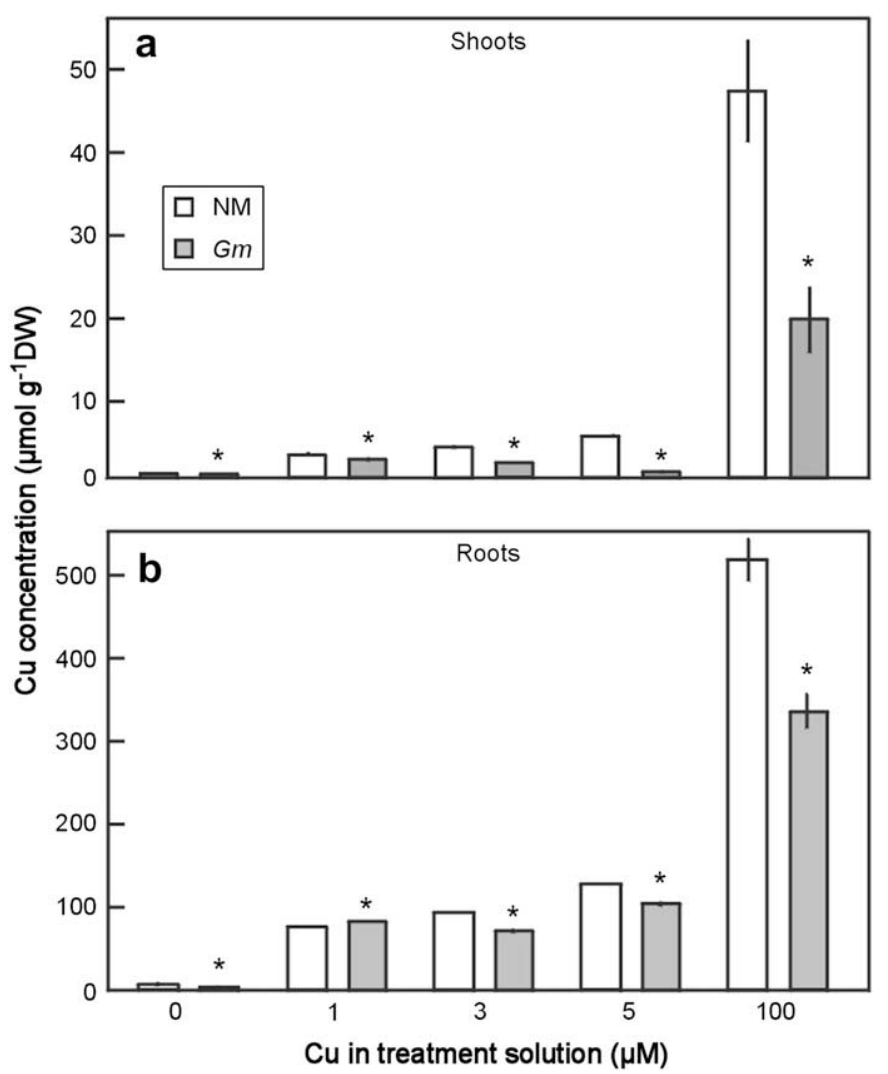

Fig. 2. Effect of mycorrhizal colonisation on the concentrations of $\mathrm{Cu}$ in roots and shoots of rice. Each point is the mean \pm standard error of 4 replicates. Asterisks indicate significant difference between mycorrhizal treatment $(\mathrm{Gm})$ and the non-mycorrhizal (NM) control $(P<0.05)$.

Measurement of the total uronic acid concentration showed that these acidic groups were significantly more abundant in the cell walls from roots of $\mathrm{Gm}$ plants compared to NM plants (Table 1).

Binding studies with the various cell wall fractions confirmed that $\mathrm{Gm}$ roots were able to bind a greater amount of $\mathrm{Cu}$ in the pectin plus hemicellulose 1 (HC1) fraction than the same fraction from NM plants (Table 2). In both mycorrhizal and non-mycorrhizal plants there remained a significant amount of bound $\mathrm{Cu}$ that could not be attributed to either of the pectin + hemicellulose fractions. This fraction was significantly higher in the Gm plants (Table 2).

\section{Discussion}

\subsection{The effects of mycorrhizal colonisation on Cu uptake by rice}

It has been well documented that mycorrhizal colonisation can have significant impacts on metal uptake by host plants (Weissenhorn and Leyval, 1995; Chen et al., 2007). The mechanisms to explain the altered uptake have mainly focused on metal immobilization in the root and/or mycorrhizosphere (Marschner, 1995). The results of the current experiments show that mycorrhizal colonisation improves the ability of rice plants to resist $\mathrm{Cu}$ toxicity. Mycorrhizal colonisation decreased $\mathrm{Cu}$ concentrations in the roots and shoots under 3, 5 and $100 \mu \mathrm{M} C u$ treatments, with a concomitant increase in root and shoot biomass. It is possible that the reduced $\mathrm{Cu}$ concentrations were partially due to the improved growth as a result of mycorrhizal colonisation, i.e. growth dilution effect, but the results presented here suggest that $\mathrm{Cu}$ immobilization on roots could be a major factor. Extensive binding of $\mathrm{Cu}$ to roots and ectomycorrhizae has been shown in other studies (Turnau, 1998; Kaldorf et al., 1999).

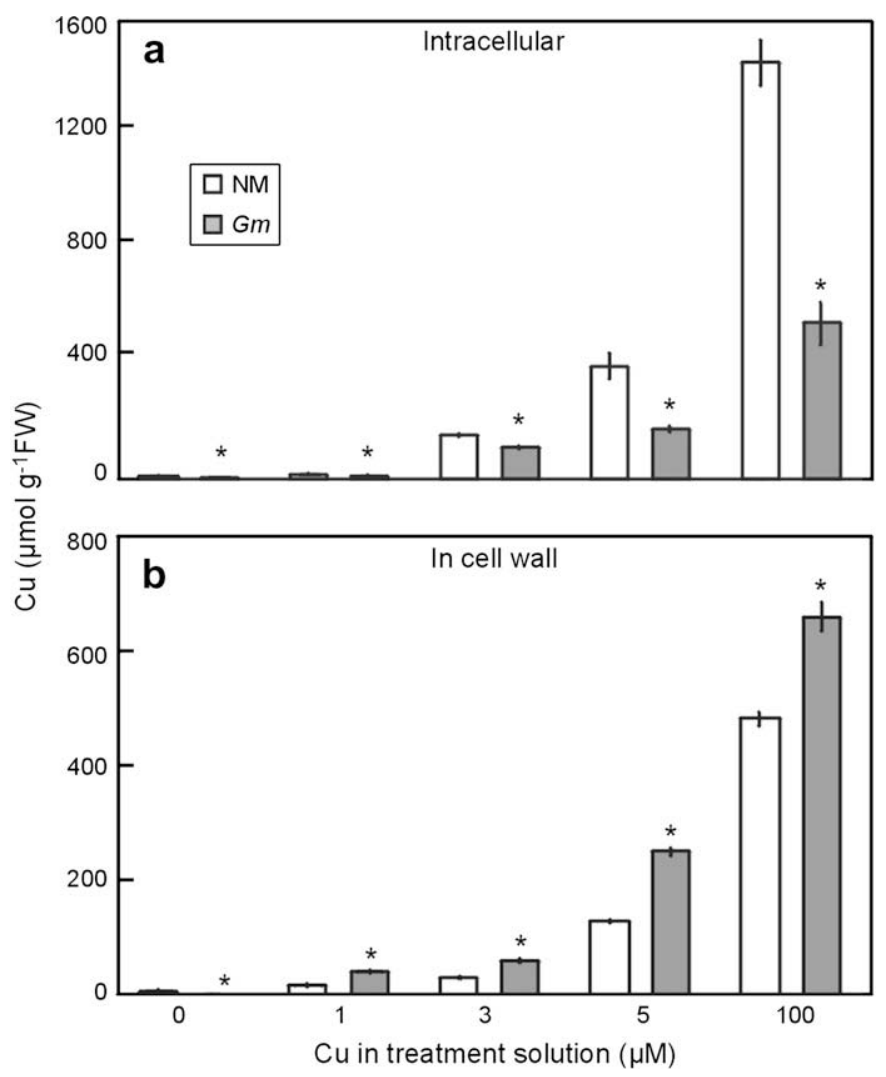

Fig. 3. Effect of mycorrhizal colonisation on the distribution of $\mathrm{Cu}$ in roots of rice. Each point is the mean \pm standard error of 4 replicates. Asterisks indicate significant difference between mycorrhizal treatment $(\mathrm{Gm})$ and the non-mycorrhizal (NM) control $(P<0.05)$.

In agreement with the literature (Li et al., 1991; Lin et al., 2007), a substantial reduction in $\mathrm{Cu}$ accumulation in shoots of the mycorrhizal plants was observed, and the reduction became more noticeable under Cu-toxic conditions (Fig. 2a). However, the corresponding differences in $\mathrm{Cu}$ accumulation in roots were relatively small, and the cause of the reduced root to shoot transfer in mycorrhizal plants was not immediately obvious from measurements of total root Cu content. The 'roots' of mycorrhizal plants are a composite structure of two organisms whose abilities to adsorb or absorb heavy metals are not necessarily the same. The distribution

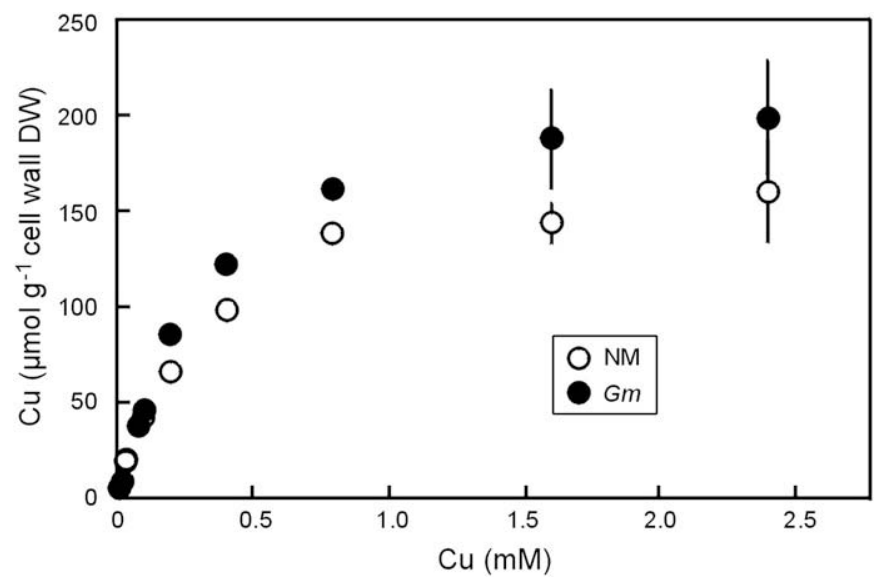

Fig. 4. Concentration dependence of $\mathrm{Cu}$ binding in cell walls isolated from mycorrhizal $(\mathrm{Gm})$ and non-mycorrhizal (NM) rice roots. Each point is the mean \pm standard error of 4 determinations. 


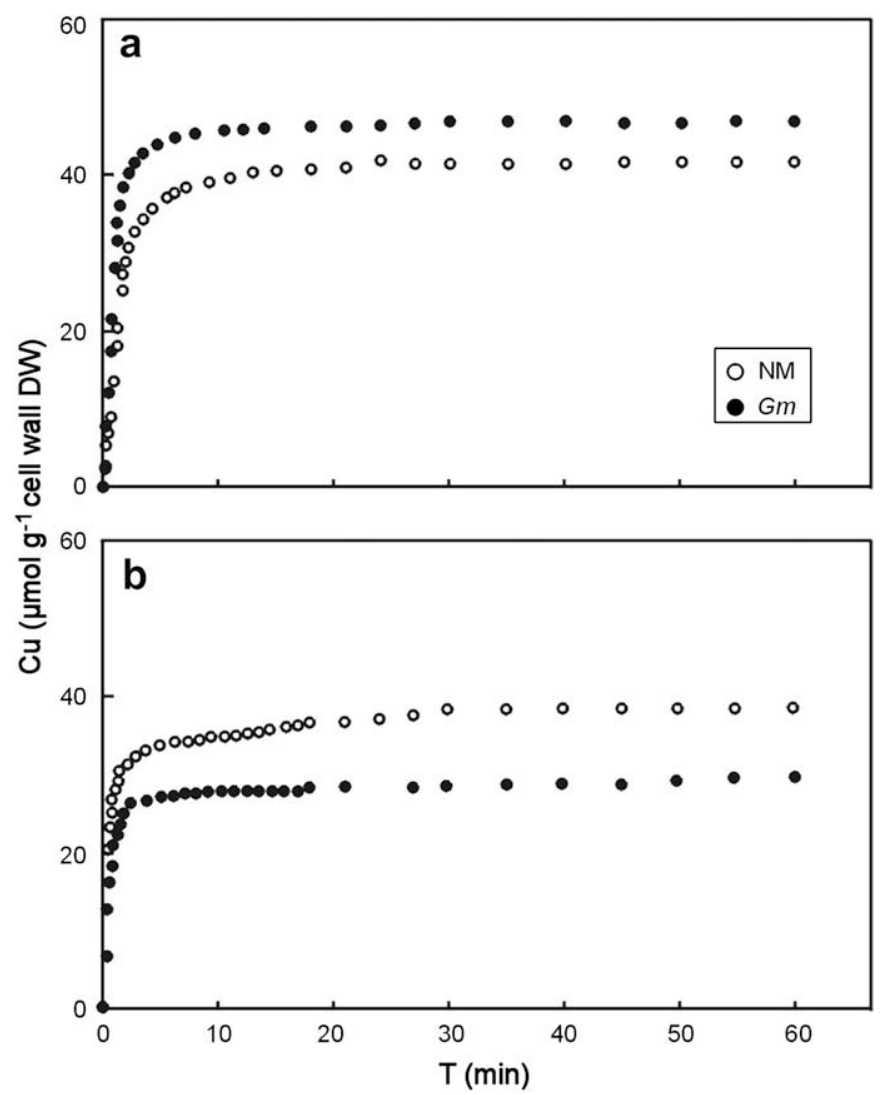

Fig. 5. Time course of $\mathrm{Cu}$ binding to isolated root cell walls extracted from of mycorrhizal $(\mathrm{Gm})$ and non-mycorrhizal $(\mathrm{NM})$ rice plants. Cu concentration $=100 \mu \mathrm{M}$. (a) Crude cell wall fraction, (b) crude cell wall fraction after removal of pectin and HC1. Each point is a single measurement.

of $\mathrm{Cu}$ between the apoplast and symplast may play a key role in $\mathrm{Cu}$ toxicity, and mycorrhizal colonisation may change the $\mathrm{Cu}$ distribution between these two components. Separation of the root $\mathrm{Cu}$ into symplastic and apoplastic fractions revealed that the mycorrhizal plants had substantially less $\mathrm{Cu}$ inside the cells, and more bound in the plant and fungal cell walls. The reduced symplastic $\mathrm{Cu}$ content correlates well with the magnitude of the reductions in shoot $\mathrm{Cu}$. The lower symplastic content of mycorrhizal plants was associated with an increase in the $\mathrm{Cu}$ content of the cell walls of mycorrhizal plant roots. We hypothesize that there is a causal relationship between retention of $\mathrm{Cu}$ in the cell walls and uptake across the plasma membrane into the root cells, leading to a lower extent of transfer to the shoots.

\subsection{Characteristics of $\mathrm{Cu}$ binding in cell walls}

The range of $\mathrm{Cu}$ adsorbed by the cell wall was between 2.6 and $3.0 \mathrm{mg} \mathrm{g}^{-1}$ cell wall. This range is in accordance with $\mathrm{Cu}$-sorption studies using soil fungi, e.g. Aspergillus niger (2-10 $\mathrm{mg} \mathrm{Cu} \mathrm{g}^{-1}$ ) and

Table 1

Differences in the proportion of cell wall and uronic acid content of roots of mycorrhizal (Gm) and non-mycorrhizal (NM) rice seedlings.

\begin{tabular}{lll}
\hline Inoculation & Cell wall (\% root FW) & $\begin{array}{l}\text { Uronic acid }\left(\mathrm{mg} \mathrm{g}^{-1}\right. \\
\text { cell wall DW) }\end{array}$ \\
\hline $\mathrm{NM}$ & $8.04 \pm 0.06 \mathrm{a}$ & $1.14 \pm 0.003 \mathrm{a}$ \\
$\mathrm{Gm}$ & $8.81 \pm 0.03 \mathrm{~b}$ & $1.40 \pm 0.04 \mathrm{~b}$ \\
\hline
\end{tabular}

Data are means \pm standard error of the mean. $n=4$ for cell wall $\%$, and $n=3$ for uronic acid content.

Different letters in each column indicate significant differences $(P<0.05)$.
Table 2

The $\mathrm{Cu}$ binding capacity of different components of cell walls extracted from mycorrhizal and non-mycorrhizal roots equilibrated with $100 \mu \mathrm{M} \mathrm{Cu}$.

\begin{tabular}{llrrr}
\hline Inoculation & \multicolumn{4}{l}{ Cu bound $\left(\mu \mathrm{mol} \mathrm{g}{ }^{-1} \mathrm{DW}\right)$} \\
\cline { 2 - 5 } & Cell wall total & \multicolumn{1}{c}{$\mathrm{P}+\mathrm{HC} 1$} & \multicolumn{1}{c}{$\mathrm{HC}$} & Remainder \\
\hline $\mathrm{NM}$ & $41.6 \pm 0.2 \mathrm{~b}$ & $3.4 \pm 0.4 \mathrm{~b}$ & $23.3 \pm 0.3 \mathrm{a}$ & $14.9 \pm 0.1 \mathrm{~b}$ \\
$\mathrm{Gm}$ & $47.0 \pm 0.8 \mathrm{a}$ & $19.0 \pm 1.6 \mathrm{a}$ & $6.8 \pm 1.6 \mathrm{~b}$ & $21.3 \pm 1.0 \mathrm{a}$ \\
\hline
\end{tabular}

Note: The binding capacities of the various fractions were calculated from the amount removed by successive treatments. $\mathrm{P}+\mathrm{HC} 1=$ pectin plus hemicellulose 1 fraction; $\mathrm{HC} 2=$ hemicellulose 2 fraction; remainder $=\mathrm{Cu}$ remaining bound after removal of pectin, $\mathrm{HC} 1$ and $\mathrm{HC} 2$ fractions. Data are expressed as mean \pm standard error of the mean. $n=3, P<0.05$.

Mucor rouxii (1-3 mg Cug ${ }^{-1}$ ) (Mullen et al., 1992; Kapoor and Viraraghavan, 1995), Rhizopus arrhizus (1.5 $\left.\mathrm{mg} \mathrm{Cu} \mathrm{g}^{-1}\right)$, Trichoderma viride (2.2 $\mathrm{mg} \mathrm{Cu} \mathrm{g}^{-1}$ ) (Morley and Gadd, 1995) and G. mosseae (3-14 $\mathrm{mg} \mathrm{Cu} \mathrm{g}^{-1}$ ) (Gonzalez-Chavez et al., 2002). A higher Cu-sorption capacity was observed in the cell walls of mycorrhizal roots compared to non-mycorrhizal roots, which may reflect differences in cell wall chemistry (Gadd, 1993; Kapoor and Viraraghavan, 1995). It was noted that mycorrhizal plants had a slightly greater percentage (10\%) of total root cell wall material which by itself would not account for the increase in binding described in Fig. 3b. Metal binding capacity is correlated with the density of acidic polysaccharides whose dissociation exposes anionic side groups capable of complexing cations, or simply reducing their mobility via electrostatic attraction (Kinraide, 1994). Various studies have identified uronic and galacturonic groups as the dominant binding moieties for $\mathrm{Cu}$ and other cations in cell walls (Zheng et al., 2004; Konno et al., 2005). In this study there was a significant increase (23\%) in uronic acids in the mycorrhizal roots which would be expected to enhance the adsorption of $\mathrm{Cu}$ $(P<0.05)$. Fractionation of the cell walls from the mycorrhizal and non-mycorrhizal plants indicated quite large shifts in the binding of the various types of polysaccharide. Mycorrhizal roots showed a 5-fold increase in $\mathrm{Cu}$ in the pectin plus hemicellulose 1 fraction, which mirrored a reduction in the binding in the hemicellulose 2 fraction (Table 2).

In general, the absorption of $\mathrm{Cu}$ by fungi and other microorganisms is a process which consists of two phases (Kapoor and Viraraghavan, 1995; Morley and Gadd, 1995; Tsezos et al., 1997; Blaudez et al., 2000; Gonzalez-Chavez et al., 2002): (a) a rapid phase, which represents the binding of $\mathrm{Cu}$ to accessible exchange sites on the surfaces of cell walls or (b) a slower phase where $\mathrm{Cu}$ diffuses into the porous cell wall structure and is sequestered or removed by other processes until an equilibrium is reached. In this study, Cu-sorption was a rapid process not only in the cell walls of intact roots but also in the purified cell wall fractions (Fig. 5). Gardea-Torresdey et al. (1997) noted that rapid $\mathrm{Cu}$ sorption was correlated with metabolism-independent sorption and most likely represented surface Cu-binding in mycelium of Mucor rouxii. Similar fast sorption processes were recorded by Joner et al. (2000) for $\mathrm{Cd}$ when the external hyphae of four isolates of arbuscular mycorrhizal fungi were incubated in solution, and by Blaudez et al. (2000) for Cd in the ectomycorrhizal fungus Paxillus involutus.

\subsection{Cu binding in fungal versus plant cell walls}

It is likely that most of the binding sites would be non-specific for $\mathrm{Cu}$ and that in complex nutrient solutions, the actual amount of $\mathrm{Cu}$ would be considerably less due to competition with other cations. It is not clear from the results presented whether the changes in partitioning of $\mathrm{Cu}$ in roots are due solely to the fact that in mycorrhizal plants there are two types of cell wall, one of which has a superior capacity for immobilising Cu (Gadd, 1993; Leyval 
et al., 1997), or whether the fungus induces changes in the composition of the cell wall of the host. Our results demonstrate that the cell walls of mycorrhizal plants are different from those of non-mycorrhizal plants, and that this difference is a causal factor in reduced $\mathrm{Cu}$ uptake into the symplasm, at least partially.

\subsection{Conclusions}

The focus of this study was to evaluate the compositional difference in cell walls between mycorrhizal roots and nonmycorrhizal roots, and the binding capacity of cell walls of mycorrhizal roots to $\mathrm{Cu}$. Overall, our results demonstrated that: 1) the reduced accumulation of $\mathrm{Cu}$ in shoots was largely due to the ability of mycorrhizal roots to limit uptake into the symplasm; 2) the reduced accumulation in the symplasm correlates well with the ability of mycorrhizal roots to bind $\mathrm{Cu}$ in the apoplasm; and 3) compositional diference in the mycorrhizal roots that explained the enhanced binding capacity of mycorrhizal roots to $\mathrm{Cu}$. All of these points provide novel insights into the mechanism of reduced $\mathrm{Cu}$ accumulation and give a sound basis for investigation of similar mechanisms for other heavy metals. Biosorption on cell walls and extracellular slime by mycorrhizal fungi and other microorganisms clearly has the capacity to alter the bioavailability of metals in the rhizosphere, thereby altering the uptake into the plant.

\section{Acknowledgements}

This study was supported by the Natural Science Foundation of China and the Ministry of Science and Technology, China. We thank Prof. Wang YS for providing arbuscular mycorrhizal fungal isolates.

\section{References}

Amado Filho, G.M., Andrade, L.R., Karez, C.S., Farinam Pfeiffer, W.C., 1999. Brown algae species as biomonitors of $\mathrm{Zn}$ and $\mathrm{Cd}$ at Sepetiba Bay, Rio de Janeiro, Brazil. Marine Environmental Research 48, 213-224.

Andrade, L.R., Farina, M., Amado Filho, G.M., 2002. Role of cell walls of Padina gymnospora (Phaeophyta) in heavy metals ( $\mathrm{Zn}$ and $\mathrm{Cd}$ ) accumulation. Phycologia 41, 39-48.

Blaudez, D., Botton, B., Chalot, M., 2000. Cadmium uptake and subcellular compartmentation in the ectomycorrhizal fungus Paxillus involutus. Microbiology 146, 1109-1117.

Bradley, R., Burt, A.J., Read, D.J., 1981. Mycorrhizal infection and resistance to heavy metal toxicity in Calluna vulgaris. Nature 292, 335-337.

Bradley, R., Burt, A.J., Read, D.J., 1982. The biology of mycorrhiza in the ericacea. The role of mycorrhizal infection in heavy metal resistance. New Phytologist 91, 197-209.

Brunner, I., Frey, B., 2000. Detection and localization of aluminum and heavy metals in ectomycorrhizal Norway spruce seedlings. Environmental Pollution 108,121-128.

Chen, B.D., Shen, H., Li, X.L., Feng, G., Christie, P., 2004. Effects of EDTA application and arbuscular mycorrhizal colonization on growth and zinc uptake by maize (Zea mays L.) in soil experimentally contaminated with zinc. Plant and Soil 261, 219-229.

Chen, B.D., Tang, X.Y., Zhu, Y.G., Christie, P., 2005. Metal concentration and mycorrhizal status of plants colonizing copper mine tailings: potential for phytoremediation. Science in China (Ser. C) 48 (Supp. I), 156-164.

Chen, B.D., Zhu, Y.-G., Duan, J., Xiao, X.Y., Smith, S.E., 2007. Effects of the arbuscular mycorrhizal fungus Glomus mosseae on growth and metal uptake by four plant species in copper mine tailings. Environmental Pollution 147, 374-380.

Cohen-Shoel, N., Ilzycer, D., Gilath, I., Tel-Or, E., 2002. The involvement of pectin in $\mathrm{Sr}^{2+}$ biosorption by Azolla. Water, Air, and Soil Pollution 135, 195-205.

Eticha, D., Stass, A., Horst, W.J., 2005. Cell-wall pectin and its degree of methylation in the maize root-apex: significance for genotypic differences in aluminium resistance. Plant, Cell and Environment 28, 1410-1420.

Feigin, A., Rylski, I., Meiri, A., Shalhevet, J., 1987. Response of melon and tomato plants to chloride-nitrate, ratio in saline nutrient solutions. Journal of Plant Nutrition 10, 1787-1794.

Frey, B., Zierold, K., Brunner, I., 2000. Extracellular complexation of Cd in the Hartig net and cytosolic Zn sequestration in the fungal mantle of Picea abies-Hebeloma crustuliniforme ectomycorrhizas. Plant Cell and Environment 23, 1257-1265.

Gadd, G.M., 1993. Interaction of fungi with toxic metals. New Phytologist 124, 25-60.

Gardea-Torresdey, J.L., Cano-Aguilera, I., Webb, R., Gutierrez-Corona, F., 1997. Enhanced copper adsorption and morphological alterations of cells of copperstressed Mucor rouxii. Environmental Toxicological Chemistry 16, 435-441.
Giovannetti, M., Mosse, B., 1980. An evaluation of techniques for measuring vesicular-arbuscular mycorrhizal infection in roots. New Phytologist 84, 489-500.

Gonzalez-Chavez, C., D’Haen, J., Vangronsveld, J., Dodd, J.C., 2002. Copper sorption and accumulation by the extraradical mycelium of different Glomus spp. (arbuscular mycorrhizal fungi) isolated from the same polluted soil. Plant and Soil 240, 287-297.

Hall, J.L., 2002. Cellular mechanisms for heavy metal detoxification and tolerance. Journal of Experimental Botany 53, 1-11.

Joner, E.J., Briones, R., Leyval, C., 2000. Metal-binding capacity of arbuscular mycorrhizal mycelium. Plant and Soil 226, 227-234.

Joner, E.J., Leyval, C., 1997. Uptake of ${ }^{109} \mathrm{Cd}$ by roots and hyphae of a Glomus mosseae/ Trifolium subterraneum mycorrhiza from soil amended with high and low concentrations of cadmium. New Phytologist 135, 353-360.

Kaldorf, M., Kuhn, A.J., Schroder, W.H., Hildebrandt, U., Bothe, H., 1999. Selective element deposits in maize colonized by a heavy metal tolerance conferring arbuscular mycorrhizal fungus. Journal of Plant Physiology 154, 718-728.

Kapoor, A., Viraraghavan, T., 1995. Fungal biosorption - an alternative treatment option for heavy metal bearing wastewater: a review. Bioresearch Technology 53, 195-206.

Kinraide, T.B., 1994. Use of a Gouy-Chapman-stern model for membrane-surface electrical potential to interpret some features of mineral rhizotoxicity. Plant Physiology 106, 1583-1592.

Konno, H., Nakato, T., Nakashima, S., Katoh, K., 2005. Lygodium japonicum fern accumulates copper in the cell wall pectin. Journal of Experimental Botany 56, 1923-1931.

Leyval, C., Turnau, K., Haselwandter, K., 1997. Effect of heavy metal pollution on mycorrhizal colonization and function, physiological, ecological and applied aspects. Mycorrhiza 7, 139-153.

Li, X.L., Marschner, H., George, E., 1991. Acquisition of phosphorus and copper by VA-mycorrhizal hyphae and root-to-shoot transport in white clover. Plant and Soil 136 (1), 49-57.

Lignell, A., Roomans, G.M., Pederson, M., 1982. Localization of adsorbed cadmium in Fucus vesiculosus L. by X-ray microanalysis. Zeitschrift fur Pflanzenphysiologie 105, 103-109.

Lin, A.J., Zhang, X.H., Wong, M.H., Ye, Z.H., Lou, L.Q., Zhu, Y.G., 2007. Increase of multi-metal tolerance of three leguminous plants by arbuscular mycorrhizal fungi colonization. Environmental Geochemistry and Health 29 (6), 473-481.

Marschner, H., 1995. Mineral nutrition of higher plants. Academic Press, London.

Morley, G.F., Gadd, G.M., 1995. Sorption of toxic metals by fungi and clay minerals. Mycological Research 99, 1429-1438.

Mullen, M.D., Wolf, D.C., Beveridge, T.J., Bailey, G.W., 1992. Sorption of heavy metals by the soil fungi Aspergillus niger and Mucor rouxii. Soil Biological Biochemistry 24, 129-135.

Parker, D.R., Norvell, W.A., Chaney, R.L., 1993. GEOCHEM-PC-a chemical speciation program for IBM and compatible personal computers. In: Loeppert, R.H., Schwab, A.P., Goldberg, S. (Eds.), Soil Chemical Equilibrium and Reaction Models. Soil Science Society of America, Madison (WI), USA, pp. 253-269.

Pellegrini, M., Laugier, A., Sergent, M., Phan-Tan-Lun, R., Valls, R., Pellegrini, L., 1993. Interactions between the toxicity of heavy metals cadmium, copper, zinc in combinations and detoxifying role of calcium in the brown alga Cystoseira barbata. Journal of Applied Phycology 5, 351-361.

Phillips, J.M., Hayman, D.S., 1970. Improved procedures for clearing roots and staining parasitic and vesicular arbuscular mycorrhizal fungi for rapid assessment of infection. Transactions of the British Mycorrhizal Society 55, 158-160.

Reid, R., Liu, J.H., 2004. Measurement of trace metal influx in plants, a case study with Co. Functional Plant Biology 31, 941-947.

Sanitá di Toppi, L.S., Gabbrielli, R., 1999. Response to cadmium in higher plants. Environmental and Experimental Botany 41, 105-130.

Tam, P.C.F., 1995. Heavy metal tolerance by ectomycorrhizal fungi and metal amelioration by Pisolithus tinctorius. Mycorrhiza 5, 181-187.

Taylor, K.A., Buchanan-Smith, J.G., 1992. A colorimetric method for the quantitation of uronic acids, and a specific assay for galacturonic acid. Analytical Biochemistry $201,190-196$

Tsezos, M., Remoudaki, K., Angelatou, V., 1997. Biosorption sites of selected metals using electron microscopy. Comparative Biochemistry and Physiology 118A, 481-487.

Turnau, K., 1998. Heavy metal content and localization in mycorrhizal Euphorbia cyparissias from zinc wastes in southern Poland. Acta Societatis Botanicorum Poloniae 67, 105-113.

Wagner, G.J., 1993. Accumulation of $\mathrm{Cd}$ in crop plants and its consequences to human health. Advances in Agronomy 51, 173-212.

Weissenhorn, I., Leyval, C., 1995. Root colonization of maize by a Cd-sensitive and a Cd-tolerant Glomus mosseae and cadmium uptake in sand culture. Plant and Soil 175, 233-238.

Zhang, X.H., Zhu, Y.G., Chen, B.D., Lin, A.J., Smith, S.E., Smith, F.A., 2005. Arbuscular mycorrhizal fungi contribute to the resistance of upland rice to combined metal contamination of soil. Journal of Plant Nutrition 28, 2065-2077.

Zheng, S.J., Lin, X.Y., Yang, J.L., Liu, Q., Tang, C.X., 2004. The kinetics of aluminum adsorption and desorption by root cell walls of an aluminum resistant (Triticum aestivum L.) cultivar. Plant and Soil 261, 85-90.

Zhong, H.L., Lauchli, A., 1993. Changes of cell-wall composition and polymer size in primary roots of cotton seedlings under high salinity. Journal of Experimental Botany 44, 773-778. 